rere med sit sprog, og det er præcis, hvad metaforer er: menneskets måde at orientere sig på i tale og handling. Når AFJ analyserer Descartes så har han ingen hermeneutisk interesse $i$ at spørge til og tænke med Descartes' begreber. Hvorfor placerer Descartes Gud i ophøjet transcendens? - Det er ikke, fordi OP ER GODT, men snarere ønsker Descartes med sin "metafor" at lade den pege ud over enhver menneskelig relationalitet, hvilket antydes i ordet "infiny". Både L\&J og AFJ vil naturligvis fastholde, at det mislykkes for Descartes, for sproget er metaforisk struktureret, og det betyder, at mennesket ikke kan springe over sig selv, når det ytrer sig. Det er sandt, hvis mennesket er målet for alt, der er til.

Jonas Holst Sorensen

\section{Den bedste af alle verdener}

Peter Thielst, Den bedste af alle verdener. De store utopier og de små visioner, København: Tiderne Skifter, 2001, $160 \mathrm{~s}$.

Peter Thielsts lille bog om de store utopier minder på en måde om en udvidet udgave af den type 'uddybende' temaartikler, som med ujævne mellemrum gerne fylder en side eller to (ofte kultursektionens eller søndagsbilagets forside) i de større danske dagblade. Typisk vil en af avishusets mere erfarne skribenter eller en formidlingsivrig og markedsførbar forsker udfolde sig om et aktuelt, men facetteret emne som f.eks. prævention, selvmordsaktioner, krigsstrategi, madlavning, skolegang, prisfastsættelse osv. Nogle gange laves der en hel serie af artikler, og så er temaet ikke sjældent hentet fra forskellige mytologier (de syv dødssynder, apokalypsens fire riddere, de ni muser). Der er nogle historiske anstrøg, et strejf af antropologi, lidt skitsering af teoretiske opfattelser, men altid uden at emnets aktualitet glider af syne (det er jo trods alt et dagblad, der skrives). Den dannede dagbladslæser glædes ved disse artikler, og har man ikke tid til omveje fra overfladen lige nu, gemmes artiklen til senere læsning. For artiklerne er interessante, de omhandler et tema ' $\mathrm{i}$ tiden', som man gerne vil have mere at vide om; man tilbydes historisk belysning, anekdoter og baggrundsstof, der står ud fra avisens sædvanlige dag-til-dag reportager - man læser opmærksomt og stilles tilfreds. Men måske angår denne tilfredshed snarere ens eget valg af en 'kultiveret' avis, som jo beviseligt har 'uddybende' læsestof; for to dage senere kan man måske huske, at man har læst artiklen, men næppe hvad man lærte af den. Eller tværtimod - i den nok hyppigst forekommende situation 
- man har lagt artiklen til side for senere læsning, men den ryger ved et uheld i papircontaineren eller bruges til optænding. Hvor stort savn føler man ikke, når man alligevel ikke får læst en af disse 'uddybende' artikler? - Nej, vel? Det er præcist den samme mangel på savn, man bør føle, dersom man ikke får læst Thielsts bog om utopierne.

Det er på ingen måde nogen skam for en bog, at den ønsker at være aktuel og respondere på et påtrængende fænomen i tiden - snarere tværtimod. Peter Thielst erklærer da også fra starten, at bogen primært er en reaktion på 'tidens' mange krav om visioner i samfundstænkningen. Disse aktuelle og krævende råb er imidlertid hverken en- eller samstemmige, men oprinder fra en mangfoldighed af brogede motiver, interesser og baggrunde. Denne spredning er formodentligt en medvirkende årsag til, at de efterlyste visioner ikke så let lader sig udkrystallisere. Det er i så fald 'tidsåndens' (eller dens erstatnings) kakafoniske vilkår, der resulterer i en forvirring, som Thielsts bog ikke gør meget for at udrede.

Tværtimod, bogen selv er øjensynligt forvirret om, hvilken slags reaktion, den udgør. Er den et svar $p a ̊$ den aktuelle visionsefterlysning? - bogens karakter af katalog over prominente utopiske samfundsmodeller kunne tyde på det. Er den et svar til den samme råben? - det indtryk får man af den ironi og sarkasme, som an- vendes, når det aktuelle visionssavn omtales. Vil den undersøge, hvorfor vor tid mangler visioner (subsidiært: hvorfor den mener at den mangler visioner)? - så tages der aldrig fat for alvor. Vil den vise, hvad de klassiske utopier kan tilbyde vor visionsløse tid? - det mener forordet vist, selv om der annonceres præsentation snarere end kritisk behandling af de overleverede luftkasteller. Eller vil den snarere udforske, hvad det er med utopien - som genre ("den tænkning, der udfolder sine visioner i skitseringen af idealsamfund, gennemtænkte modeller for samliv, produktion og menneskelig lykke," p.12) og i dens konkrete udformninger - der gør den inkompatibel med de aktuelle ønsker om fornyet samfundsteoretisk idérigdom? - det indtryk udspringer af de direkte kommentarer til de enkelte modeller, og (noget modvilligt) af de afsluttende bemærkninger.

Måske findes der forfattere, der ville kunne skrive en bog, der på overbevisende facon var alle disse ting på én gang, men det ville (bl.a.) kræve, at man gik systematisk til og i dybden med stoffet på en måde, som Thielst undlader i denne omgang. Ifølge forordet er undladelsen ingen forsømmelse, men en beslutning - hensigten er at præsentere og inspirere snarere end kritisere og analysere - men det er alligevel synd. Som læser kunne man nemlig netop ønske en historisk og analytisk tilgang til det specifikt utopiske, såvel som til de konkrete utopiers styrker 
og svagheder i filosofisk, politisk og receptionshistorisk henseende. Og måske kunne man også forvente, at en idéhistoriker ville opfylde dette ønske, f.eks. gennem en systematisk udfoldelse af de overordnede temaer, der nævnes $i$ indledningen. Her opkastes nemlig flere frugtbare utopikarakteristika - hvoraf den afgørende nok er paradokset mellem statik og dynamik.

Hvis denne problematik havde fået styre så meget af fremstillingen, som bogens titel antyder, kunne Den bedste af alle verdener være blevet en rigtig interessant bog. Som Thielst anfører, er utopien - en gennemtænkt model for den bedste af alle verdener - i selve dens eksistens et udtryk for, at man ikke lever $\mathrm{i}$ den bedste af alle verdener, men at dette dog er muligt. Sagt med andre ord er der en tilstand af imperfektion, der muliggør (eller fremkalder) idealet om en perfekt tilstand, som den mindre-end-perfekte kan transformeres til. Utopien er således dynamisk i sin anlægning, men statisk i sin udlægning; for når utopien er realiseret, vil det ideale mål være opnået og der vil ikke være rum for forbedringer. Enhver forandring - og herunder kritik, der kan anspore til forandring - vil $i$ den utopiske tilstand være per definition degenererende og uønsket.

Paradokset omkring dynamik og statik samler således en række af de mest karakteristiske træk og problematikker ved de klassiske utopier - deres optimisme og ud- viklingstanke, deres rationalisme, der skal løse samfundets interessekonflikter, deres tendens til realiseret totalitarisme, deres opblomstring i de historiefilosofiske stadielærers tid og (formodentligt) deres klodsethed i en tid som vores, der tager tankens imperfektion (og ikke, som Thielst antyder, samfundets perfektion) som et grundlæggende vilkår. Samtidigt udstiller disse træk mange af utopiernes problemer, f.eks. at selv om der fundamentalt forudsættes en udviklingsgang og -mulighed, gives der sjældent blot tilnærmelsesvis plausible beskrivelser af, hvordan en sådan udvikling kunne forløbe. Ofte er det bare en rationalistisk åbenbaring, der (fast og vedblivende!) overbeviser samfundsmedlemmerne om identiteten mellem individets og samfundets interesser, eller (som hos Frederik Christian Sibbern, 1785-1872) menneskene vågner simpelthen en morgen og betragter alt som fælles, uden antydning af "egennytte, ærgærrighed, harme, forvirrelse, forbitrelse" osv. (p.137; denne paradisiske mentale indstilling indtræffer dog ikke i Trondhjem, Island og Amerika). Der vil altså i utopierne ofte være tale om ikke blot en ny samfundsorganisering, men også om et nyt menneske, som passer umådeligt godt til denne organisering, og derfor er lykkeligt. I den forbindelse træder utopiernes karakter af skrivebordsarbejder også frem, som det, man med henvisning til Kardemommeby (som dog ikke er med blandt Thielsts utopier) kan 
kalde Tante Sofie-syndromet: "Hvis alle blot var som mig, så ville alt blive godt."

En systematisk behandling af denne type karakteristika kunne have frembragt en frugtbar analytisk struktur for en mere dybtgående behandling af de enkelte utopier og interessante betragtninger over utopien og dens tid (måske også om vor egen). Desværre nævnes de mere almene træk kun overordnet $\mathrm{i}$ indledningen, og afstedkommer kun sporadiske nedslag i gennemgangen af de konkrete utopier. Teoretiske refleksioner over utopiens væsen gives en mindre rolle endnu; efter en kort præsentation af Ernst Blochs 'anticiperende bevidsthed' og Marx/Engels 'ideologi' i indledningen hører vi stort set ikke mere om den side af sagen.

I stedet for en teoretisk begrundet og begrebsligt reflekteret analyse fremstilles et præsentationskatalog over det, forfatteren i forordet kalder "de væsentligste filosofiske utopier gennem de sidste 2500 år." Som sådant katalog kan bogen selvsagt have sin berettigelse (om end noget mindre ambitiøs end ønskværdigt er) gennem "at formidle et stykke idéhistorie, der sjældent kommer til orde i egen ret, og fremvise rariteter fra tankens laboratorium" (p.12). Forfatteren vil dog gerne mere end dette, nemlig også inspirere - men bogen skulle nok gå mindst et spadestik dybere, hvis den skulle blive interessant nok til at opnå dette. På trods af enkelte informative positi- ons-skitser og nogle underholdende passager fremstår utopi-kataloget som underligt rodet og halvfærdigt, delvis i strid med de udtalte hensigter og utopi-kriterier.

Allerede den første beskrivelse af idealsamfundet - Platons Staten - volder forfatteren problemer i forhold til hans afgrænsning af det utopiske. Samfundsprospektet er nemlig her ikke væsentligt et forlæg til realisering, men en sidegevinst ved en filosofisk diskussion om, hvad retfærdighed er. Endvidere må man sige, at netop dette værk næppe hører til den mest oversete del af idéhistorien og det er svært at se, hvad Thielsts gennemgang af det i et 'utopi'-perspektiv egentligt bidrager med. Mindre kendte er de tanker, der fremlægges af den græsk-jødiske Filon (10 f.Kr.-45) og af Joachim af Fiori (1135-1202), men omvendt fremgår det ikke synderligt godt, hvordan Filons asketiske terapeuter (som måske er historiske snarere end utopiske) kan inspirere dagens søgen efter visioner. Joachims idéer om det tredje rige synes snarere at have haft betydning som historiefilosofisk end som samfundsorganisatorisk skitse.

Bogens bedste kapitler er gennemgangene af de klassiske utopier, Thomas Mores Utopia, Tomasso Campanellas Solstaten og Francis Bacons Det ny Atlantis, samt det om de utopiske socialister, hvor især Charles Fourier har forfatterens velvillige opmærksomhed. Man ville ønske, at han havde koncentreret sig stærkere om 
denne periode og til gengæld ladet dens utopier undergå en grundigere og mere stringent analyse. Alle de væsentlige pointer ved det utopiske, såvel som de mest fuldendte visioner, fremkommer nemlig her. Samtidigt ville han næppe have kunnet undgå at behandle spørgsmålet om den utopiske tænknings historiefilosofiske og idéhistoriske status.

Interessant - men netop som " rariteter fra tankens laboratorium" - er også kapitlet om 'de danske' utopister: Holberg (i Niels Klim), David Frederik Spichmann (182045), nævnte Sibbern, samt 1970'ernes Opror fra midten. Imidlertid kniber det med at anskueliggøre, at det nationale indslag, vurderet ud fra dets idémæssige bidrag, har en selvsagt plads i en lille bog om "de væsentligste filosofiske utopier gennem de sidste 2500 år." Noget uforståeligt er det også, at Holberg kommer med blandt utopisterne $\mathrm{i}$ kapitel 8 , når han regnes som udenfor $\mathrm{i}$ indledningens afgrænsning af en definition (p.15). Men tilsvarende skal denne definition om "den filosofisk udarbejdede utopi" (p.15), som "gennemtænkte modeller for samliv, produktion og menneskelig lykke," (p.12) jo også kunne bruges om John Lennons "Imagine".

Det er denne form for unøjagtigheder, omtrentligheder og uhensigtsmæssige selvmodsigelser, der irriterer under læserens forsøg på at finde gennemgående pointer og en klar profil i bogen. I mangel af en bærende analyse opløses bogen i en håndfuld måde- ligt interessante skitser af udformede utopier, som imidlertid igen fortaber sig $\mathrm{i}$ forfatterens snakkesalighed og springende argumentation. Nogle vil måske opfatte det som veltalenhed og intellektuel oplagthed, men for denne anmelder fremstår det som forvirrende name-dropping og umotiverede henvisninger $\mathrm{i}$ øst og vest. Eksempelvis bliver (p.10) evangelisten Mattæus krediteret for udtrykket "sanke i lade", som betegner det, der blev muligt med overgangen til agerbrugssamfundet for "ca. 10.000 år" siden. Men hvilken autoritet er Mattæus egentlig i denne sammenhæng? - næppe nogen, når det angår tidsfastsættelsen, i hvert fald; eller er det selve udtrykket, der i den grad er 'hans'? Et andet eksempel er Michel Foucault, hvis analyse af Benthams 'Panopticon' inddrages som illustration af opbygningen af Campanellas Solstat (p.78). Dette sker, selv om det tydeligvis ikke er tale om noget sammenfald hverken i udformning eller (som Thielst indrømmer) i funktion. I det hele taget dukker Foucaults navn op med jævne mellemrum, selv om han ikke citeres for at sige noget særligt vigtigt, og slet ikke om utopien. (Derimod undersøges ikke - hvilket kunne være interessant og substantielt - Foucaults sidebemærkning i Ordene og Tingene om, at utopierne går fra at være regressive (henvise til en 'guldalder') til at blive progressive i den periode hans værk behandler.) Man kunne få den tanke, at den 'tid', der råber på "visioner", også råber på 
"Foucault", og at Thielst vil levere til begge former for efterspørgsel.

Bogen er ikke noget makværk, men skæmmet af venstrehåndsarbejde og mangel på stringens, der kunne have givet den analytisk bæreevne og en markant profil. Som læser får man - med et blik på Thielsts publikationsliste de senere år - følelsen af at have $i$ hænde en lidt for hurtig sammenskrivning af genbrug og rester fra forfatterens senere produktion Til forfatterens forsvar kan det siges, at han her ikke har ambitioner om at lave idéhistorisk forskning og fraskriver sig analytiske bestræbelser, til fordel for markedstilpasset formidling. Omvendt må det fastholdes, at han dermed forspilder mange gode anledninger til at producere et virkeligt værdifuldt værk. Men desværre synes forfatteren at opfatte kravet om aktualitet som uforeneligt med systematik, og vælger det første. Resultatet bliver en temmelig overflødig bog, hvor rod og forvirring må gøre det ud for nuancer og mangfoldighed, og hvis hårdt pressede dyd bliver, at den omtaler visse positioner, der er mindre kendte i den offentlige debat. Men inspirerende eller blot rigtigt interessant bliver den egentligt aldrig.

Knut Anton Bockman

\section{"Alt hvad du no- gensinde onskede at vide om revo- lutionæer socialisme, men ikke turde spørge Paulus om"}

Slavoi Zizek, Det skrøbelige absolutte - eller hvorfor er den kristne arv værd at kæmpe for?, Moderne tænkere - Gyldendal, København 2001, 272 sider, 295 kr.

Som en indledning må det vist være på sin plads at undskylde min anmeldelses lange titel. Som formildende omstændighed (eller som en forsøgsvis forklaring på dette forhold) må det nævnes, at der rent faktisk er tale om en omskrivning af en titel på en bog - Everything You Always Wanted to Know about Lacan (But Were Afraid to Ask Hitchcock) - som Zizek selv var med til at redigere tilbage i 1988. Når det nu er sagt, så lader fantasifulde titler i det hele taget til at være lidt af et særkende for den slovenske psykoanalytiker, filosof og ideologikritikker Slavoj Zizeks (f. 1949) efterhånden ganske omfattende forfatterskab, der dog også på et mere tematisk niveau kredser omkring fantasien - eller sagt mere præcist: Menneskets uerkendte (undertrykte?) fantasier og begær, og hvorledes disse kan siges at forklare og i nogen grad determinere vore handlinger som agenter $\mathrm{i}$ det politiske. 